\title{
Konstytucyjność regulacji normującej sytuację wnioskodawców w procedurze naboru projektów w systemach realizacji programów operacyjnych według orzecznictwa Trybunału Konstytucyjnego
}

Wyrokiem Trybunału Konstytucyjnego z dnia 12 grudnia 2011 r. ${ }^{1}$ za niezgodne $\mathrm{z}$ art. 87 Konstytucji Rzeczypospolitej Polskiej² (który ustala zamknięty katalog źródeł prawa powszechnie obowiązującego) zostały uznane trzy przepisy ustawy z dnia 6 grudnia $2006 \mathrm{r}$. o zasadach prowadzenia polityki rozwoju ${ }^{3}$, a mianowicie:

- art. 5 pkt 11 przez to, że dopuszcza uregulowanie praw i obowiązków wnioskodawców w trakcie naboru projektów finansowanych z programu operacyjnego poza systemem źródeł powszechnie obowiązującego prawa,

- art. 30b ust. 1 zdanie pierwsze i ust. 2 w zakresie, w jakim dopuszcza uregulowanie środków odwoławczych przysługujących wnioskodawcy w toku postępowania o dofinansowanie z programu operacyjnego poza systemem źródeł powszechnie obowiązującego prawa,

- art. 30c ust. $1 \mathrm{w}$ zakresie, w jakim uzależnia prawo do skorzystania ze skargi do sądu administracyjnego od wyczerpania środków odwoławczych przewidzianych w aktach niebędących źródłami powszechnie obowiązującego prawa.

Trybunał Konstytucyjny zdecydował jednocześnie, że przepisy te tracą moc obowiązującą we wskazanym zakresie z upływem 18 miesięcy od dnia ogłoszenia wyroku w Dzienniku Ustaw.

W orzeczeniu tym częściowo rozstrzygnięto wątpliwości wysuwane przez przedstawicieli nauki prawa w stosunku do uregulowań ustawy o zasadach prowadzenia polityki rozwoju. Warto zastanowić się nad niektórymi podstawo-

* Prof. nadzw. dr hab. Wiesława Miemiec - Katedra Prawa Finansowego, Wydział Prawa, Administracji i Ekonomii, Uniwersytet Wrocławski.

** Mgr Przemysław Pest - Katedra Prawa Finansowego, Wydział Prawa, Administracji i Ekonomii, Uniwersytet Wrocławski.

Sygn. akt P 1/11.

${ }^{2}$ Konstytucja Rzeczypospolitej Polskiej z 2 kwietnia 1997 r., Dz. U. z 1997 r. Nr 78, poz. 483 ze zm. (dalej: Konstytucja RP).

${ }^{3}$ Dz. U. z 2009 r. Nr 84, poz. 712 ze zm. (dalej: u.z.p.p.r.). 
wymi tezami powołanego orzeczenia Trybunału Konstytucyjnego oraz wskazać na ewentualne skutki wyroku dla reguł określających finansowanie projektów i programów z udziałem bezzwrotnych środków europejskich w Polsce.

\section{Zagadnienie niekonstytucyjności niektórych regulacji ustawy o zasadach prowadzenia polityki rozwoju wskazywanych przez naukę prawa finansowego}

Wątpliwości co do regulacji ustawy o zasadach prowadzenia polityki rozwoju, w tym także w zakresie konstytucyjności niektórych jej przepisów, były wskazywane w doktrynie już przed powołanym wyrokiem Trybunału Konstytucyjnego. Zgłaszane w literaturze przedmiotu uwagi co do przepisów tej ustawy można podzielić na cztery grupy.

Pierwsza grupa przedstawianych przez naukę wątpliwości dotyczy niezgodności z Konstytucją art. 5 pkt 11 u.z.p.p.r., który zawiera definicję legalną zakresu przedmiotowego systemu realizacji programów operacyjnych. Zgodnie $\mathrm{z}$ tą definicją system realizacji ustala zasady i procedury obowiązujące instytucje uczestniczące $\mathrm{w}$ realizacji strategii rozwoju oraz programów, obejmujące zarządzanie, monitoring, ewaluację, kontrolę i sprawozdawczość oraz sposób koordynacji działań tych instytucji. System realizacji określa również środki odwoławcze przysługujące wnioskodawcy w trakcie naboru projektów, o których mowa w art. 28 ust. 1 pkt 3 u.z.p.p.r. W literaturze przedmiotu podkreślano, że systemy realizacji regionalnych programów operacyjnych stanowione $\mathrm{w}$ formie uchwał zarządu województwa nie są aktami prawa powszechnie obowiązującego. Zawierają one m.in. normy regulujące zasady zarządzania, sprawozdawczości, kontroli i oceny oraz sposobu koordynacji działań instytucji uczestniczących w realizacji, a więc instytucji zarządzających, instytucji pośredniczących, instytucji wdrażających oraz beneficjentów. Co za tym idzie, jeżeli systemy realizacji byłyby wyłączną podstawą kontroli u beneficjenta przez instytucje wdrażające, to takie rozwiązanie należy uznać za wątpliwe pod względem zgodności ze wskazanym art. 87 Konstytucji ${ }^{4}$. Dodatkowo odwoływano się do art. 11 nieobowiązującej już ustawy z dnia 20 kwietnia 2004 r. o Narodowym Planie Rozwojus, który przewidywał uzupełnienia programów operacyjnych, mających uszczegółowiać systemy realizacji programów. Co istotne, zgodnie z art. 11 ust. 5 ustawy o Narodowym Planie Rozwoju, uzupełnienie programu miało formę rozporządzenia właściwego ministra (a więc aktu prawa powszechnie obowiązującego, wymienionego w konstytucyjnym katalogu źródeł prawa) albo uchwały zarządu województwa ${ }^{6}$. Postulo-

${ }^{4} \mathrm{~K}$. Borowicz, Zasady prowadzenia polityki rozwoju. Ustawa z dnia 6 grudnia $2006 \mathrm{r}$ z komentarzem, Warszawa 2008, s. 40.

${ }^{5}$ Dz. U. Nr 116, poz. 1206 ze zm.

${ }^{6} \mathrm{~K}$. Borowicz, op. cit., s. 41. 
wano zatem, aby także obecnie określanie reguł zarządzania, sprawozdawczości, kontroli i oceny oraz sposobów koordynacji działań instytucji uczestniczących w realizacji przybierało formę rozporządzenia ${ }^{7}$.

Druga grupa wątpliwości sygnalizowała niezgodność z Konstytucją materii będącej przedmiotem regulacji systemów realizacji regionalnych programów operacyjnych, dotyczących sytuacji prawnej osób aplikujących o dofinansowanie środków z bezzwrotnych źródeł europejskich. Zgodnie z art. 15 ust. 1 u.z.p.p.r. „programy są dokumentami o charakterze operacyjno-wdrożeniowym, ustanawianymi w celu realizacji średniookresowej strategii rozwoju kraju oraz strategii rozwoju [...] określającymi działania przewidziane do realizacji zgodnie z ustalonym systemem finansowania i realizacji, stanowiącym element programu". Programy przyjmuje się w drodze uchwały (w przypadku organu kolegialnego) lub decyzji organu (w przypadku organu jednoosobowego). Z kolei przepis art. $30 \mathrm{~b}$ ust. 1 u.z.p.p.r. przewiduje zasady regulacji środków odwoławczych, które mogą być wnoszone przez wnioskodawcę w przypadku negatywnej oceny projektu, w systemie realizacji programu operacyjnego, w terminie, trybie i na warunkach tam określonych. Artykuł $30 \mathrm{~b}$ ust. 2 u.z.p.p.r. stanowi, że system realizacji programu operacyjnego musi uwzględniać co najmniej jeden środek odwoławczy przysługujący wnioskodawcy w trakcie ubiegania się o dofinansowanie. Zakres ustawowej regulacji dotyczącej możliwości zaskarżenia wyniku oceny projektu zawarty jest zatem tylko w niewielkiej części w samej ustawie. Zasadniczo natomiast jest ustalany w treści poszczególnych systemów realizacji programów operacyjnych. Wskazywano zatem, iż zgodnie $\mathrm{z}$ art. $30 \mathrm{~b}$ ust. 1 u.z.p.p.r. systemy realizacji programu operacyjnego faktycznie normują materię ustawową. Krytykowano także samą zasadę wynikającą z art. 30b u.z.p.p.r., według którego organ administracji sam wydaje przepisy, które stanowią następnie podstawę prawną podejmowanych przez niego czynności. W konsekwencji formułowano wątpliwości, powołując się na treść art. 77 ust. 2 oraz art. 78 Konstytucji RP, kreujących zasadę prawa do sądu oraz zasadę dwuinstancyjności, stanowiąc, że ustawa nie może nikomu zamykać drogi sądowej dochodzenia naruszonych wolności lub praw, a każda ze stron ma prawo do zaskarżenia orzeczeń i decyzji wydanych w pierwszej instancji. Stawiane było pytanie, czy system realizacji programu operacyjnego, niebędący aktem prawa powszechnie obowiązującego, jest wystarczającą podstawą prawną dla normowania konstytucyjnego prawa do odwołania i prawa do sądu ${ }^{8}$. Zgodnie bowiem z art. 78 zd. 2 Konstytucji RP, wyjątki od zasady, iż każda ze stron ma prawo do zaskarżenia orzeczeń i decyzji wydanych w pierwszej instancji oraz tryb zaskarżania winna określać ustawa ${ }^{9}$. W badanym natomiast przypadku tryb

${ }^{7}$ Ibidem, s. $40-41$.

${ }^{8}$ M. Szubiakowski, Postępowanie $w$ sprawie rozdziału środków $w$ ramach polityki rozwoju oraz sadowa kontrola $w$ tych sprawach, „Zeszyty Naukowe Sądownictwa Administracyjnego” 2009 , nr 4, s. 32.

9 Ibidem, s. 33. 
zaskarżenia określa akt prawny niebędący źródłem prawa. Ponadto, akt ten powinien być kwalifikowany jako akt wewnętrznie obowiązujący. Przepis art. 30b ust. 1 u.z.p.p.r. reguluje zatem prawa i obowiązki wnioskodawcy, a więc podmiotu niepodlegającego organizacyjnie organowi wydającemu te akty (por. art. 93 ust. 1 i 2 Konstytucji RP) ${ }^{10}$. W literaturze przedmiotu sygnalizowano również problem zakresu ochrony prawnej przed działaniami organu administracyjnego. Przepisy Konstytucji generalnie gwarantują niewiążący charakter aktów prawa wewnętrznego wobec podmiotów niepodlegających organizacyjnie wydającym je organom administracyjnym. Jednak w przypadku ustawy o zasadach prowadzenia polityki rozwoju podporządkowanie się aktom prawa wewnętrznego jest wymuszone. Zgodnie z art. 30c u.z.p.p.r. realizacja konstytucyjnego prawa do sądu jest bowiem uzależniona od wyczerpania środków odwoławczych przewidzianych $\mathrm{W}$ systemie realizacji programu operacyjnego, a więc $\mathrm{w}$ akcie prawnym nienależącym do katalogu aktów powszechnie obowiązujących ${ }^{11}$.

Trzecia grupa omawianych uwag dotyczy statusu wytycznych wydawanych w oparciu o przepisy ustawy o zasadach prowadzenia polityki rozwoju. Zgodnie z art. 35 ust. 3 u.z.p.p.r. minister właściwy do spraw rozwoju regionalnego, w celu zapewnienia zgodności sposobu wdrażania programów operacyjnych z prawem Unii Europejskiej oraz spełniania wymagań określanych przez Komisję Europejską, a także w celu zapewnienia jednolitości zasad wdrażania programów operacyjnych, może, z uwzględnieniem art. 26 u.z.p.p.r., wydać wytyczne dotyczące programów operacyjnych. Przepis ten wylicza kwestie, które mogą być uregulowane w wytycznych. Kontrowersje w doktrynie budzi przede wszystkim regulacja pkt 2 wskazanego artykułu, zgodnie z którym wytyczne mogą być wydawane w zakresie trybu dokonywania wyboru projektów oraz pkt 11, według którego wytyczne mogą być wydawane w zakresie innych spraw związanych z przygotowaniem i wdrażaniem programów operacyjnych. Wątpliwości w zakresie tego, czy wytyczne mogą mieć wiążący charakter w stosunku do podmiotów funkcjonujących poza strukturą administracji rządowej, były wskazywane w literaturze przedmiotu już od dłuższego czasu ${ }^{12}$. Bez wątpienia, tak jak w przypadku

10 Ł. M. Wyszomirski, O sprzeczności z Konstytucją ustawy o zasadach prowadzenia polityki rozwoju, „Forum Prawnicze” 2011, nr 4-5, s. 117.

11 Ibidem, s. 118-119.

12 W. Miemiec, Dochody budżetu jednostki samorzadu terytorialnego pochodzace z budżetu UE oraz innych źródet zagranicznych niepodlegajacych zwrotowi, [w:] C. Kosikowski (red.), Finanse samorzadowe 2008. 410 pytań i odpowiedzi. Wzory uchwat, deklaracji, decyzji, Warszawa 2008, s. 238; W. Miemiec, Ogólne zasady kwalifikowalności wydatków dokonywanych przez jednostki samorządu terytorialnego $w$ związu z finansowaniem projektów i programów ze środków funduszy strukturalnych i Funduszy Spójności Unii Europejskiej, [w:] B. Filipiak, A. Szewczuk (red.), Samorzad terytorialny w zintegrowanej Europie. IV Forum Samorządowe, Szczecin 2008, s. 258; W. Miemiec, Finanse Wspólnoty Europejskiej jako źródło finansowania wydatków publicznych i prywatnych w Polsce, [w:] J. Głuchowski, C. Kosikowski, J. Szołno-Koguc (red.), Nauka finansów publicznych i prawa finansowego w Polsce. Dorobek i kierunki rozwoju. Księga jubileuszowa 
systemów realizacji programów operacyjnych, wytyczne nie są źródłem prawa powszechnie obowiązującego. Wytyczne nie powinny być więc wiążące w stosunku do podmiotów funkcjonujących poza strukturą administracji publicznej. Analizując jednak ustalony zakres zagadnień, które są regulowane wytycznymi, a także tryb ich przygotowywania, można wskazać na dysonans między zamiarem ustawodawcy a wymogami konstytucyjnymi źródeł prawa powszechnie obowiązującego. Wydaje się bowiem, że celem ustawodawcy było nadanie wytycznym wiążącego charakteru wobec wszystkich podmiotów uczestniczących w poszczególnych etapach wdrażania oraz wykonywania programów operacyjnych, pomimo nienadawania im charakteru źródła prawa powszechnie obowiązującego ${ }^{13}$. W rezultacie instytucję wytycznych proponowano uznać za niezgodną z art. 87 Konstytucji RP oraz z art. 93 ust. 2 zdanie drugie Konstytucji RP, ponieważ regulują one prawa i obowiązki podmiotów niepodlegających organom wydającym te wytyczne ${ }^{14}$. W doktrynie wskazuje się również, że nad rozstrzygnięciami podejmowanymi na podstawie wytycznych lub na podstawie systemów realizacji programu operacyjnego wprowadzono $\mathrm{w}$ art. 30c u.z.p.p.r. kontrolę administracyjną, która winna być przeprowadzana w oparciu o kryterium legalności. Akty normatywne wewnętrznie obowiązujące nie powinny być jednak brane pod uwagę w takiej kontroli ${ }^{15}$. Oznacza to, że sądy administracyjne w procesie kontroli informacji o ocenach projektów nie powinny oceniać działań organów (instytucji zarządzającej lub instytucji pośredniczącej) przez pryzmat wytycznych. Jedynie w przypadku, gdyby wytyczne naruszały przepisy powszechnie obowiązujące i w oparciu o te przepisy została wydana negatywna ocena projektu, sąd administracyjny uwzględniłby skargę wskazując, że dane wytyczne nie powinny mieć zastosowania w sprawie skargi na tę konkretną ocenę ${ }^{16}$. Warto nadmienić, że w doktrynie prezentowane jest również odmienne stanowisko na temat charakteru prawnego wytycznych. Wskazuje się, że pomimo braku wymienienia wytycznych w konstytucyjnym katalogu źródeł prawa należy je uznać de facto

Profesor Alicji Pomorskiej, Lublin 2008, s. 473; D. Zając, Kwalifikowalność wydatków w projektach jednostek samorzadu terytorialnego wspólfinansowanych z Programu Operacyjnego Kapitat Ludz$k i$, ,Finanse Komunalne” 2011, nr 9, s. 27.

${ }_{13} \mathrm{~W}$. Miemiec, Zasady pozyskiwania i wykorzystania bezzwrotnych środków zagranicznych, [w:] E. Ruśkowski (red.), System prawa finansowego, t. 2: Prawo finansowe sektora finansów publicznych, Warszawa 2010, s. 354-355.

${ }^{14}$ Por. E. Kornberger-Sokołowska, Środki europejskie w systemie środków publicznych w Polsce, [w:] A. Dobaczewski, E. Juchniewicz, T. Sowiński (red.), System finansów publicznych, Warszawa-Gdańsk 2010, s. 113.

15 W. Miemiec, Zasady pozyskiwania i wykorzystania..., s. 376-377; W. Miemiec, Dopuszczalność drogi przed sądem administracyjnym w postępowaniu aplikacyjnym o bezzwrotne środki unijne, [w:] Księga pamiątkowa prof. Apoloniusza Kosteckiego, Kraków 2012, s. 281.

${ }^{16} \mathrm{~K}$. Sobieralski, Rola sądów administracyjnych $w$ polskim porządku prawnym a kontrola oceny projektu, [w:] W. Miemiec (red.), Europejskie bezzwrotne źródta finansowania polityki regionalnej w Polsce. Aspekty prawno-finansowe, Wrocław 2012, s. 303-304. 
za akty prawa powszechnie obowiązującego. Stanowisko to jest motywowane koniecznością szybkiego regulowania zagadnień problemowych w zakresie pozyskiwania środków unijnych, bez potrzeby przeprowadzania długiego procesu ustawodawczego. Ma się to przyczynić do szybkości i efektywności wykorzystywania środków pochodzących z budżetu Unii Europejskiej ${ }^{17}$.

Czwarta grupa wątpliwości dotyczy konstrukcji ustawy o zasadach prowadzenia polityki rozwoju, której wiele instytucji nie przystaje do polskiego porządku prawnego. W literaturze przedmiotu wskazuje się, że regulacje prawne dotyczące procedur rozdzielania środków europejskich nie są spójne z regulacjami kodeksu postępowania administracyjnego ${ }^{18}$ oraz prawa o postępowaniu przed sądami administracyjnymi ${ }^{19}$. W praktyce budzi to wiele kontrowersji w procesie ich stosowania ${ }^{20}$. Dla przykładu można wskazać, że do procedury konkursowej wprowadzono instytucję „decyzji”, a do procedury weryfikacyjnej „odwołania”. Obydwie instytucje prawne mają ustalone znaczenie na gruncie postępowania administracyjnego. Tymczasem art. 37 u.z.p.p.r. stanowi, że do postępowania na podstawie ustawy w zakresie ubiegania się oraz udzielania dofinansowania ze środków pochodzących z budżetu państwa lub ze środków zagranicznych nie stosuje się przepisów kodeksu postępowania administracyjnego ${ }^{21}$. W literaturze przedmiotu do pojęć, które na gruncie ustawy o zasadach prowadzenia polityki rozwoju otrzymały swoiste znaczenie, pomimo ustalonego znaczenia w polskim porządku prawnym oraz braku wprowadzenia w ustawie definicji legalnych tych terminów, zalicza się m.in.: „otrzymanie”, ,instytucję”, „informację”, „dokument”22. W doktrynie reprezentowane jest nawet stanowisko, że stosowana w tym przypadku technika prawodawcza, która wprowadza do ustawy siatkę pojęciową nieprzystającą do rozwiązań powszechnie przyjętych w prawie polskim, stanowi naruszenie jednej z podstawowych zasad prawidłowej legislacji - a mianowicie zasady określoności prawa, a co za tym idzie - naruszenie art. 2 Konstytucji, z którego zasadę tę się wywodzi ${ }^{23}$. Podobne wątpliwości zgłaszane są w zakresie styku ustawy o zasadach prowadzenia polityki rozwoju z przepisami postępowania przed sądami administracyjnymi. W literaturze przedmiotu wskazuje się, że regulacja art. 30e u.z.p.p.r., która nakazuje jedynie odpowiednie stosowanie p.p.s.a. z pewnymi wyłączeniami, jest przykładem dekodyfikacji ogól-

17 J. Zdanukiewicz, Mechanizmy realizacji polityk unijnych, [w:] E. Kornberger-Sokołowska, J. Zdanukiewicz, R. Cieślak, Jednostki samorzadu terytorialnego jako beneficjenci środków europejskich, Warszawa 2010, s. 100.

${ }^{18}$ Ustawa z dnia 14 czerwca 1960 r. Kodeks postępowania administracyjnego, Dz. U. z 2000 r. Nr 98, poz. 1071 ze zm. (dalej: k.p.a.).

19 Ustawa z dnia 30 sierpnia 2002 r. Prawo o postępowaniu przed sądami administracyjnymi, Dz. U. z 2012 r. Nr 270 (dalej: p.p.s.a.).

${ }^{20}$ E. Kornberger-Sokołowska, op. cit., s. 113.

${ }^{21}$ W. Miemiec, Zasady pozyskiwania $i$ wykorzystania..., s. 376-377.

${ }^{22}$ Ł. M. Wyszomirski, op. cit., s. 114-115.

${ }^{23}$ Ibidem. 
nych przepisów o postępowaniu przed sądami administracyjnymi ${ }^{24}$. Dodatkowo warto przypomnieć zasygnalizowaną już kwestię przenoszenia materii ustawowej (np. regulacja instytucji odwołania) do przepisów niemających charakteru powszechnie obowiązującego ${ }^{25}$.

\section{Podstawowe tezy uzasadnienia wyroku Trybunału Konstytucyjnego}

Postępowanie przed Trybunałem Konstytucyjnym zainicjował Wojewódzki Sąd Administracyjny w Łodzi, zwracając się do Trybunału z pytaniem prawnym: ,[...] czy art. 5 pkt 11, art. 30b ust. 1 i 2 oraz art. 30c ust. 1 u.z.p.p.r. są zgodne $\mathrm{z}$ art. 2, art. 7, art. 31 ust. 3, art. $87 \mathrm{i}$ art. 184 Konstytucji”. Kwestia ta jest istotna $\mathrm{z}$ uwagi na regulację art. 66 ustawy z dnia 1 sierpnia 1997 r. o Trybunale Konstytucyjnym ${ }^{26}$, zgodnie z którym Trybunał, orzekając, jest związany granicami wniosku, pytania prawnego lub skargi. W uzasadnieniu orzeczenia Trybunał zauważa bowiem, w kontekście formy prawnej systemów realizacji programów operacyjnych: „iż ani jednolita praktyka organów administracji, ani spójne orzecznictwo sądów administracyjnych nie mogą zastąpić bezpośredniego uregulowania formy prawnej systemów realizacji w zaskarżonej ustawie. To, jakie podmioty i w jaki sposób mają prawo normować sytuację uczestników konkursów organizowanych w ramach regionalnych programów operacyjnych, ma istotne znaczenie nie tylko praktyczne, lecz także prawne. Pominięcie tej kwestii w ustawie o zasadach prowadzenia polityki rozwoju może być oceniane przez pryzmat zasady zaufania obywateli do państwa i stanowionego przez nie prawa, a w dalszej kolejności także zasady prawidłowej legislacji. Ze względu na związanie Trybunału Konstytucyjnego zakresem zaskarżenia wskazanym w pytaniu prawnym powyższa konstatacja nie może wprawdzie znaleźć wyrazu w sentencji niniejszego orzeczenia, niemniej stanowi istotny element oceny badanych regulacji”.

Wydaje się więc, że Trybunał zauważa i sygnalizuje w ten sposób inne możliwe naruszenia Konstytucji w badanej ustawie, lecz będąc związanym granicami pytania prawnego, nie może odnieść się do nich bezpośrednio. Należy również zaznaczyć, że Trybunał nie znalazł podstaw dla stwierdzenia naruszenia w badanym zakresie art. 2, art. 7, art. 31 ust. 3 oraz art. 184 Konstytucji RP. Podstawowe rozważania uzasadnienia wyroku dotyczą wątpliwości występujących w związku z naruszeniem art. 87 Konstytucji RP.

${ }^{24}$ K. Sobieralski, Regulacja prawna postępowania sadowo-administracyjnego, [w:] W. Miemiec (red.), Europejskie bezzwrotne źródła finansowania polityki regionalnej w Polsce. Aspekty prawno-finansowe, Wrocław 2012, s. 300.

${ }^{25}$ M. Szubiakowski, op. cit., s. 33.

${ }^{26}$ Dz. U. z 1997 r. Nr 102, poz. 643 ze zm. 
Zasadnicza część uzasadnienia orzeczenia Trybunału rozpoczyna się od przedstawienia ogólnych uwag na temat systemów realizacji programów operacyjnych. Następnie Trybunał przedstawił krótko obowiązujący w Polsce system źródeł prawa i w tym kontekście zajął się trzema zasadniczymi kwestiami związanymi z relacją art. 5 pkt 11, art. 30b ust. 1 i 2 oraz art. 30c ust. 1 u.z.p.p.r. z art. 87 Konstytucji RP, tj. miejscem systemów realizacji programów operacyjnych w systemie źródeł prawa, zakresem podmiotowym systemów realizacji oraz ich zakresem przedmiotowym.

Trybunał Konstytucyjny, oceniając miejsce systemów realizacji wśród źródeł prawa, wskazuje na liczne orzeczenia sądów administracyjnych dotyczące tej materii. W tym zakresie Trybunał stwierdza, że ,analiza całokształtu dorobku orzeczniczego sądów administracyjnych w omówionym zakresie prowadzi do wniosku, że pogląd o traktowaniu systemów realizacji jako źródeł prawa sui generis, niebędących aktami prawa powszechnie obowiązującego w rozumieniu art. 87 Konstytucji, jest powszechnie przyjęty w judykaturze. Odstępstwa od takiego umiejscawiania systemów realizacji mają charakter jednostkowy. Występowały jedynie w początkowej fazie orzekania przez sądy na podstawie ustawy o polityce rozwoju [...]. Trybunał Konstytucyjny podziela prezentowany w omówionym wyżej orzecznictwie sądów administracyjnych pogląd, że systemów realizacji nie można zaliczyć do źródeł prawa powszechnie obowiązującego, a w tym do aktów prawa miejscowego [...]. Systemy realizacji nie są bowiem wydawane przez podmioty konstytucyjnie upoważnione do stanowienia aktów powszechnie obowiązujących i nie mają formy wskazanej dla tych aktów w Konstytucji”. Trybunał stwierdza więc jednoznacznie, że systemów realizacji nie można uznać za źródło prawa powszechnie obowiązującego. Trybunał wskazuje jednak, że „powyższa konstatacja [...] nie może jednak być samoistnym powodem uznania niezgodności kwestionowanych przepisów z art. 87 Konstytucji. Może być nim dopiero ustalenie, że przewidziana przez zaskarżone regulacje treść systemu realizacji wymaga w sposób konieczny uregulowania w aktach prawa powszechnie obowiązującego".

Drugą kwestią rozpatrywaną przez Trybunał było wskazanie zakresu podmiotowego systemów realizacji. Trybunał stwierdził, że przepisy, których dotyczyło pytanie prawne, są skierowane zarówno do organów państwa, jak i do osób fizycznych, osób prawnych i jednostek organizacyjnych ubiegających się o dofinansowanie ze środków unijnych. Co za tym idzie, Trybunał wskazał, że „w świetle Konstytucji RP i opartego na niej orzecznictwa, podmiotów tych nie można uznać za «jednostki organizacyjnie podległe» organowi, który wydał system realizacji (tj. zarządowi województwa). Regulowanie ich sytuacji prawnej za pomocą systemu realizacji programu operacyjnego jest więc absolutnie niedopuszczalne. Oceny tej nie zmienia ewentualna zgoda samych zainteresowanych na poddanie się regulacjom konkursowym".

Odnośnie zakresu przedmiotowego systemów realizacji Trybunał wskazał, że „mają (one) bezpośredni wpływ na realizację praw i wolności obywateli 
i z tego powodu stanowią materię zarezerwowaną dla aktów prawa powszechnie obowiązującego. [...] Samoistnie uregulowane są w nim m.in. harmonogramy konkursów, kryteria oceny projektów czy procedura odwoławcza od negatywnych wyników konkursów na etapie przedsądowym (w tym terminy i forma zaskarżenia, a także instytucje odpowiedzialne za rozpatrzenie odwołań)". Trybunał stwierdził również, że „szczególnie drastycznym naruszeniem art. 87 Konstytucji jest zwłaszcza «delegacja» do uregulowania $\mathrm{w}$ systemie realizacji procedury odwoławczej, przysługującej uczestnikowi konkursu [...]. W tym bowiem zakresie zastosowanie mają jednoznaczne przepisy Konstytucji, nakazujące uregulowanie trybu zaskarżania «decyzji wydanych w pierwszej instancji» (którymi w tym wypadku są wyniki oceny projektów) w akcie powszechnie obowiązującego prawa, a dokładniej - wyłącznie w formie ustawy (art. 78 Konstytucji)".

Trybunał w uzasadnieniu badanego orzeczenia wskazał nie tylko na fakt, iż systemy realizacji z uwagi na treść unormowań zostały wydane przez organ, który nie ma konstytucyjnych upoważnień do wydania takich przepisów, ale także na to, iż systemy realizacji regionalnych programów operacyjnych nie zostały opublikowane w sposób powszechnie przyjęty dla publikacji aktów normatywnych.

Na podstawie analizy powyższych zagadnień Trybunał uznał, że przepisy, których dotyczyło pytanie prawne, są niezgodne z art. 87 Konstytucji. Zdaniem Trybunału wynika to z faktu, że systemy realizacji programów operacyjnych, nie będąc źródłami prawa powszechnie obowiązującego, regulują prawa i obowiązki wnioskodawców projektów, niebędących podmiotami organizacyjnie podległymi wobec organów wydających systemy realizacji, a zwłaszcza te dotyczące procedury odwoławczej.

\section{Skutki wyroku Trybunału Konstytucyjnego}

Stanowisko Trybunału przedstawione w tym orzeczeniu zasługuje na pełną aprobatę. Jak to wykazano w uzasadnieniu orzeczenia, systemy realizacji regionalnych programów operacyjnych (przyjmowane w formie uchwał zarządów województw) regulują nie tylko kompetencje organów administracji odpowiedzialnych za organizację tych konkursów, tj. zasady i procedury obowiązujące m.in. podczas konkursów na dofinansowywanie projektów z bezzwrotnych środków europejskich. Normują one również sytuację uczestników konkursów (tj. prawa i obowiązki osób fizycznych, osób prawnych wyposażonych w zdolność prawną i innych podmiotów funkcjonujących poza strukturą administracji publicznej, dotyczące kryteriów oceny zgłoszonych wniosków czy rodzaje środków odwoławczych przysługujących im $\mathrm{w}$ razie odmowy ich finansowania $\mathrm{w}$ ramach konkursów). Kwestie te regulowane są w drodze aktów wewnętrznych, niezaliczonych do konstytucyjnego katalogu źródeł prawa powszechnie obowiązującego, 
przewidzianego przez art. 87 Konstytucji RP. Sytuację taką w kontekście ustaleń Trybunału, dotyczących zakresu podmiotowego, przedmiotowego i formy prawnej oraz sposobu publikacji badanych systemów realizacji, należy uznać niewątpliwie za niezgodną z Konstytucją. Prawa i obowiązki uczestników konkursów powinny być regulowane wyłącznie w formie aktów prawnych stanowiących źródła prawa, tj. w ustawach czy rozporządzeniach.

Utrata mocy obowiązującej zakwestionowanych przepisów ustawy o zasadach prowadzenia polityki rozwoju nastąpi dopiero w połowie 2013 r. Trybunał odroczył, jak to wskazano, utratę mocy badanych przepisów aż o 18 miesięcy, licząc od dnia ogłoszenia wyroku w Dzienniku Ustaw. Omawiane orzeczenie zalicza się zatem do orzeczeń z odroczoną datą wejścia w życie, wydawanych w trybie art. 190 ust. 3 Konstytucji RP. Należy w związku z tym postawić pytanie, jakie są skutki takiego orzeczenia Trybunału. Czy konkursy, które będą rozstrzygane do końca obecnej perspektywy finansowej (tj. do 2013 r.) będą mogły być rozstrzygane i oceniane według dziś obowiązujących, ale uznanych za niekonstytucyjne przepisów ustawy o zasadach prowadzenia polityki rozwoju i wydanych na jej podstawie systemów realizacji regionalnych programów operacyjnych? Należy też postawić kolejne pytanie: co powinien uczynić sąd administracyjny, do którego wpłynie skarga, kwestionująca negatywny wynik procedury odwoławczej, albo wniosek o wznowienie postępowania i uchylenie ostatecznych decyzji lub rozstrzygnięć, które wydano w oparciu o przepisy ustawy, których niekonstytucyjność stwierdził Trybunał?

Według stanowiska Ministerstwa Rozwoju Regionalnego wszystkie konkursy po wydaniu orzeczenia Trybunału mogą być rozstrzygane według obowiązujących przepisów, w tym tych zaskarżonych, wobec których Trybunał orzekł niekonstytucyjność, z uwagi na odroczenie wejścia w życie orzeczenia. Przedstawiciele ministerstwa przyjęli, iż nie ma powodu zawieszać jakiejkolwiek procedury naboru, podobnie jak nie ma podstaw do wzruszania już zakończonych procedur naboru. $\mathrm{W}$ praktyce, powyższe oznacza zanegowanie niekonstytucyjności rozwiązań przyjętych w u.z.p.p.r., a dotyczących ogólnie systemu ubiegania się o dofinansowanie i utrzymanie stanowiska o niekonstytucyjności jedynie w zakresie procedury odwoławczej ${ }^{27}$.

Możliwość wzruszenia wydanych w tych sprawach decyzji ostatecznych była także przedmiotem oceny Rzecznika Praw Obywatelskich. Jak wskazywała Rzecznik w piśmie do Ministra Rozwoju Regionalnego, przewidziana w art. 190 ust. 4 Konstytucji RP możliwość ich wzruszenia sprowadza się faktycznie do fikcji prawnej ${ }^{28}$. „Procedura odwoławcza (według RPO), dotycząca dofinansowania $\mathrm{z}$ regionalnych programów operacyjnych jest do tej pory niejednolita, niespójna i budzi wiele zastrzeżeń prawnych".

\footnotetext{
27 www.funduszeeuropejskie.gov.pl.

28 Pismo RPO Nr RPO-665 405-1/11AWO.
} 
Także Trybunał w końcowej części uzasadnienia orzeczenia, odnosząc się do kwestii odroczenia daty jego wejścia w życie, zauważył, iż wznawianie postępowań o udzielenie finansowania z programów operacyjnych $\mathrm{w}$ związku z niekonstytucyjnością badanych rozwiązań podlega pewnym ograniczeniom niezależnym od odroczenia skutków tego orzeczenia. Wynikają one ze specyfiki kontrolowanej materii. Nie ma bowiem ani prawnej, ani praktycznej możliwości „odwrócenia” zakończonych konkursów prowadzonych $\mathrm{w}$ ramach regionalnych programów operacyjnych, gdyż przyznane na ich mocy ściśle określone środki zostały już rozdysponowane i wypłacone beneficjentom, a częściowo także wydane. Otwieranie na nowo w takiej sytuacji ,skonsumowanych" procedur konkursowych i ponowna ocena wszystkich wniosków o finansowanie prowadziłaby do naruszenia konstytucyjnych praw podmiotów, które uzyskały finansowanie z programów operacyjnych i w dobrej wierze skorzystały z tego finansowania. Inaczej mówiąc, pieniądze w obecnej perspektywie finansowej zostały już rozdzielone i ponowne wzruszanie ostatecznych orzeczeń nie przyczyni się do możliwości uzyskania nowych środków finansowych. Należy w tym miejscu jednak podkreślić, że w nauce prawa konstytucyjnego powszechne jest stanowisko, iż zastosowanie przez TK instytucji odroczenia wejścia w życie orzeczenia nie obliguje sądów do stosowania w czasie tego okresu przepisu niekonstytucyjnego. Przeciwnie, sąd może już nie stosować takich przepisów w okresie odroczenia ${ }^{29}$. Przyznaje się, że sposób rozstrzygnięcia w takim okresie należy do sądu, który w zależności od stanu faktycznego rozstrzyganej sprawy może odmówić zastosowania niekonstytucyjnych przepisów także w okresie odroczenia wejścia w życie wyroku TK ${ }^{30}$.

Pogląd ten znalazł także odzwierciedlenie w rozstrzygnięciach sądów administracyjnych. Początkowo, rozpatrując tego typu sprawy, wojewódzkie sądy administracyjne przyjmowały tę samą argumentację, którą wskazywał TK w omawianym uzasadnieniu. Orzekano w oparciu o jeszcze obowiązujące przepisy art. 5 pkt 11 , art. $30 \mathrm{~b}$ ust. $1 \mathrm{zd} .1 \mathrm{i}$ ust. 2 oraz art. 30c ust. 1 u.z.p.p.r., pozostawiając skargę bez rozpatrzenia. W uzasadnieniach postanowień wskazywano, że nie ma „ani prawnej, ani praktycznej możliwości odwrócenia zakończonych konkursów prowadzonych w ramach regionalnych programów operacyjnych, gdyż przyznane na ich mocy ściśle określone środki zostały już rozdysponowane i wypłacone beneficjentom"31. Od kwietnia 2012 r. jednak w podobnych sprawach zaczęly zapadać postanowienia, w których sądy - jako przyczynę odrzucania skarg - wskazują również brak legalnej drogi odwołania się od regulaminów, skoro te zostały uznane przez Trybunał za niekonstytucyjne.

${ }^{29}$ Informacje o istotnych problemach wynikajacych z działalności i orzecznictwa TK $w 2009 \mathrm{r}$, Studia i Materiały TK, Warszawa 2010, s. 122-123 i powołane tam orzecznictwo sądów.

${ }^{30} \mathrm{~K}$. Działocha, O pojęciu wykonywania orzeczeń Trybunału Konstytucyjnego, [w:] W stużbie dobru wspólnemu. Księga jubileuszowa dedykowana Profesorowi Januszowi Trzcińskiemu, Warszawa 2012, s. 420-421.

${ }^{31}$ Postanowienie WSA w Łodzi z 3 kwietnia 2012 r., sygn. akt SA /Łd 165/12, nieopubl. 
W literaturze pojawiło się stanowisko, iż orzeczona niekonstytucyjność przepisów ustawy o zasadach prowadzenia polityki rozwoju może pociągnąć za sobą dwojakiego rodzaju skutki. Mianowicie skutki w relacjach beneficjentów z instytucją przyznającą środki, którzy mogą występować o unieważnienie konkursów, ponieważ były one organizowane $\mathrm{z}$ pominięciem przepisów prawa oraz $\mathrm{w}$ relacji Polski jako państwa członkowskiego z organami Unii Europejskiej, które mogą nałożyć sankcję finansową na Polskę, ponieważ środki pochodzące z budżetu ogólnego UE przyznane były z pominięciem obowiązujących przepisów prawa ${ }^{32}$. Nie sposób podzielić takiego stanowiska w stosunku do każdego z rodzajów powyżej wskazanych skutków.

Jeżeli chodzi o relacje pomiędzy beneficjentem a instytucją przyznającą środki, to należy w pierwszym rzędzie podkreślić, że konkursy nie były organizowane $\mathrm{z}$ pominięciem przepisów prawa. Były one, jak to wynika z uzasadnienia orzeczenia TK, organizowane nie tylko na podstawie przepisów ustawy, ale również przepisów prawa wewnętrznego. Po drugie, dążenie do wznowienia postępowania nie będzie oznaczało możliwości realizacji celu zamierzonego przez beneficjenta. Wznawianie postępowań o udzielenie finansowania z programów operacyjnych w związku z niekonstytucyjnością badanych rozwiązań podlega pewnym ograniczeniom, jak to TK wskazał w końcowej części uzasadnienia. W przypadku pozytywnego zakończenia dla skarżącego wznowionego postępowania i unieważnienia konkursu nie będzie temu bowiem towarzyszyć możliwość uzyskania środków, o które potencjalny beneficjent aplikował. Zostały one już bowiem rozdzielone.

Nie wydaje się również zasadne, aby organy Unii Europejskiej mogły nałożyć sankcję finansową na Polskę, ponieważ środki pochodzące z budżetu ogólnego UE przyznane były z pominięciem obowiązujących przepisów prawa. Także i tutaj należy podkreślić, że przyznanie środków dla beneficjentów nie odbyło się z pominięciem przepisów prawa. Jak to wyżej ustalono, przyznanie środków odbyło się z zastosowaniem, obok przepisów ustawowych, także przepisów prawa wewnętrznego. Prawo UE, jak stwierdził TK, nie przesądza, w jakiego typu aktach prawnych mają być unormowane prawa i obowiązki podmiotów ubiegających się o środki z regionalnych programów operacyjnych. Także art. 58 rozporządzenia nr 1083/2006 w ogóle nie odnosi się do kwestii, jaka powinna być forma prawna wskazanych ,systemów zarządzania i kontroli”"33. Zatem forma kreowania właści-

${ }^{32}$ G. Karwatowicz, Niekonstytucyjne zasady prowadzenia polityki rozwoju, „Finanse Publiczne" 2012, nr 3, s. 63 .

${ }^{33}$ Art. 58 rozporządzenia nr 1083/2006 Parlamentu Europejskiego i Rady z dnia 11 lipca ustanawiający przepisy ogólnie obowiązujące dotyczące Europejskiego Funduszu Rozwoju Regionalnego, Europejskiego Funduszu Społecznego oraz Funduszu Spójności i uchylające rozporządzenie (WE) nr 1260/1999, Dz. Urz. UE L 210 z 31 lipca 2006 r., jedynie ogólnie określa zakres przedmiotowy „systemów zarządzania i kontroli”, nakazując uregulowanie w nich m.in. funkcji podmiotów uczestniczących w realizacji programów operacyjnych związanych z zarządzaniem i kontrolą oraz 
wych instrumentów dla realizacji celów została pozostawiona państwom członkowskim. Autonomia państw członkowskich w powyższej sferze jest względna, bo ograniczona przez obowiązek poszanowania ogólnych zasad ustrojowych Unii Europejskiej. Dotyczy to przede wszystkim zasady pomocniczości i proporcjonalności (przewidzianej w pkt 65 preambuły do rozporządzenia nr 1083/2006) oraz obowiązku zapewnienia jednolitego i efektywnego stosowania prawa unijnego oraz zagwarantowania temu prawu pełnej skuteczności w krajowym porządku prawnym (art. 291 Traktatu o funkcjonowaniu UE UE $^{34}$ oraz pkt 62 preambuły do rozporządzenia $\mathrm{nr} 1083 / 200$ ). Bardzo istotna jest także, zdaniem TK, zasada autonomii instytucjonalnej, której wyrazem jest zawarty w art. 12 rozporządzenia nr 1083/2006 nakaz realizacji programów operacyjnych na „właściwym szczeblu terytorialnym”, „zgodnie z systemem instytucjonalnym właściwym dla każdego państwa członkowskiego". Zatem zgodnie z zasadą autonomii proceduralnej, w razie braku norm wspólnotowych rzeczą każdego systemu krajowego, każdego państwa członkowskiego jest określenie zasad, na podstawie których wykonywane są normy prawa wspólnotowego. Jeżeli prawo Unii Europejskiej, regulując dany obszar (np. co do formy prawnej realizacji programów operacyjnych), nie przewidziało zasad ochrony praw jednostek wynikających z prawa Unii Europejskiej, właściwymi przepisami są przepisy prawa krajowego. Nie mogą być one mniej korzystne dla zainteresowanych podmiotów niż uregulowania stosowane w podobnych sytuacjach w celu ochrony praw jednostek wynikających wyłącznie z prawa wewnętrznego państw członkowskich ani powodować, że wykonywanie praw nadanych w porządku prawnym Unii stałoby się ,praktycznie niemożliwe” lub „nadmiernie utrudnione”.

Jak to już wyżej ustalono w badanej sprawie, Konstytucja RP nakazuje określenie zasad i trybu postępowania $\mathrm{w}$ sprawach o dofinansowanie $\mathrm{z}$ regionalnego programu operacyjnego w przepisach powszechnie obowiązującego prawa. Realizacja tego wymogu niewątpliwie wzmocni unijną zasadę skuteczności. Zmiana sposobu regulowania praw i obowiązków uczestników konkursów spowoduje nie tylko przywrócenie stanu zgodności z Konstytucją, ale także umożliwi bardziej efektywną realizację zobowiązań wynikających z członkostwa Polski w Unii Europejskiej. Nie ma zatem żadnych podstaw prawnych, aby można było wszcząć postępowanie przeciwko państwu polskiemu i w konsekwencji nałożyć sankcję finansową.

Rozwiązanie problemu, jak wskazuje Trybunał, wymaga pilnej interwencji ustawodawcy. W Ministerstwie Rozwoju Regionalnego trwają obecnie prace nad projektem ustawy zmieniającej ustawę o zasadach prowadzenia polityki rozwoju. Należy mieć nadzieję, że po ich zakończeniu nie będzie musiał ponownie interweniować Trybunał Konstytucyjny.

procedur zapewniających zasadność i prawidłowość wydatków zadeklarowanych w ramach programów operacyjnych.

${ }^{34}$ Traktat o funkcjonowaniu Unii Europejskiej, Dz. Urz. UE, C 115/49 z 9 maja 2008 r. 